\title{
Prevalence and risk factors for gestational diabetes mellitus according to the Diabetes in Pregnancy Study Group India in comparison to International Association of the Diabetes and Pregnancy Study Groups in El-Minya, Egypt
} Ghada M. El Sagheer ${ }^{\mathrm{a}}$, Lamia Hamdib

\author{
${ }^{a}$ Endocrinology Unit, Department of Internal \\ Medicine, ${ }^{b}$ Department of Clinical Pathology, \\ Minia School of Medicine, Minia University, \\ Minya, Egypt \\ Correspondence to Ghada M. El-Sagheer, MD \\ Internal Medicine, Diabetology and \\ Endocrinology Unit, Department of Internal \\ Medicine, Minia University Hospital, M. Badawy \\ Street, 61111 El-Minya, Egypt. \\ Tel: +20 100050 7027; fax: +20 862342 505; \\ e-mail: ghadagme70@yahoo.com \\ Received 4 March 2018 \\ Accepted 18 March 2018
}

The Egyptian Journal of Internal Medicine 2018, 30:131-139

\begin{abstract}
Background
The prevalence of gestational diabetes mellitus (GDM) has increased dramatically worldwide in the last decades, but unfortunately it was not studied in Egypt. Objective

Assessment of the prevalence of GDM in El-Minya city, Egypt using the Diabetes in Pregnancy Study Group India (DIPSI) in comparison to the International Association of the Diabetes and Pregnancy Study Groups (IADPSG) criteria, and assessment of the risk factors for GDM in this locality.

Patients and methods

There were 700 pregnant women who underwent the $75 \mathrm{~g}$ oral glucose tolerance test irrespective of the meal and plasma glucose measurement after $2 \mathrm{~h}$. In the next morning, fasting and $1 \mathrm{~h}$, and $2 \mathrm{~h}$ post- $75 \mathrm{~g}$ oral glucose tolerance test were assessed. Diagnosis of GDM was carried out according to the DIPSI and IADPSG criteria.

Results

GDM was diagnosed in 62/700 women (8.86\%) by DIPSI versus $52 / 700(7.43 \%)$ by IADPESG. Compared with IADPSG, the sensitivity and specificity of DIPSI were 100 and $98.5 \%$, respectively, while the positive and negative predictive values were 83 and $100 \%$, respectively. The multiple logistic regression analysis has shown that $\mathrm{BMI}$, urban residency, gestational hypertension, previous history of GDM, gestational hypertension, family history of DM, and the educational level less than secondary school were determined as independent risk factors of GDM.

Conclusion

The GDM prevalence in El-Minya city was $8.86 \%$ by DIPSI versus $7.43 \%$ by IADPSG with high sensitivity, specificity, and predictive values. The DIPSI could be considered as a simple, single, convenient, and economical method of GDM screening. However, more evaluation in a bigger patient sample is recommended.

\section{Keywords:}

Diabetes in Pregnancy Study Group India, gestational diabetes, International Association of the Diabetes and Pregnancy Study Groups

Egypt J Intern Med 30:131-139

(c) 2018 The Egyptian Journal of Internal Medicine 1110-7782
\end{abstract}

\section{Introduction}

With first recognition during pregnancy, carbohydrate intolerance is defined as gestational diabetes mellitus (GDM) [1-5]. This common metabolic problem is associated with several complications to the mother and the child [6]. The fetal morbidities may include macrosomia, birth trauma, hypoglycemia, hypocalcemia, hypomagnesemia, hyperbilirubinemia, polycythemia, respiratory distress syndrome [6-8], and a higher risk for childhood metabolic syndrome, and diabetes mellitus (DM) in early adulthood [3,5,6]. Mothers may have a considerably elevated risk of preeclampsia, caesarean section, infection, and polyhydramnios [6,8], and type 2 DM later on [6,9]. Also, GDM may uncover an increased risk of developing long-term cardiovascular disease both in the mother and the child $[1,4]$. The risk factors for GDM include increased parity, high maternal age, prepregnancy obesity, family history of diabetes, and obstetric history of GDM, delivery of an infant with macrosomia, or with congenital malformation [3,8-10]. With a global increase, the prevalence of GDM varies from 1 to $14 \%[5,8]$ with higher rates in Australia (Indian-born 15\%, Chinese 13.9\%) and in the USA (Zuni Indians 14.3\%) [11].

The objectives of this study were to assess the prevalence of GDM according to the Diabetes in Pregnancy Study Group India (DIPSI) criteria, and to assess its sensitivity, specificity, and predictive values in comparison to the International Association of the

This is an open access journal, and articles are distributed under the terms of the Creative Commons Attribution-NonCommercial-ShareAlike 4.0 License, which allows others to remix, tweak, and build upon the work non-commercially, as long as appropriate credit is given and the new creations are licensed under the identical terms. 
Diabetes and Pregnancy Study Groups (IADPSG) criteria and also to examine the association of GDM with a number of risk factors in a sample of the Egyptian pregnant population.

\section{Patients and methods}

This study was carried out at Minya University Hospital, in El-Minya city (230 000 population), at Upper Egypt from June 2015 to November 2015. The sample size was calculated based on a $5 \%$ prevalence of GDM with a $2 \%$ uncertainty level [12] with an estimated number of 780 patients required for the study. After approval of the study protocol from the local institutional ethics committee, we contacted the main antenatal care centers in the city to refer the pregnant women with an estimated gestational age of between 24th and 28th weeks who met the inclusion criteria and agreed to participate in the study after signing an informed consent. The exclusion criteria for this study were pre-GDM, chronic illness, and drugs that might affect pregnancy.

All the participants in the study were subjected to full history taking, through clinical examination, and laboratory investigations. The history included demographic characteristics, educational level, smoking, occupation, parity, family history of DM and/or hypertension in the first-degree relatives, past history of GDM, macrosomia (baby was born $\geq 4 \mathrm{~kg}$ ), stillbirth, or unexplained neonatal death. The clinical examination was concluded with blood pressure estimation, anthropometric measurements [weight $(\mathrm{kg})$ and height $(\mathrm{m})]$, and BMI estimation. The laboratory investigations included $2 \mathrm{~h}$ glucose level after ingestion of $75 \mathrm{~g}$ glucose (anhydrous glucose powder is dissolved in $250-300 \mathrm{ml}$ water and consumed within $5 \mathrm{~min}$ ) irrespective of the meal (fasting or nonfasting) according to the DIPSI criteria [13]. The capillary blood glucose level was estimated, and levels of at least $140 \mathrm{mg} / \mathrm{dl}$ were considered diabetic. Then all women screened by DIPSI were requested to come on overnight fasting on the following day and the $2 \mathrm{~h} 75 \mathrm{~g}$ oral glucose tolerance test (OGTT) was performed. Assessment of capillary blood glucose was done with the participant fasting, and 1 , and $2 \mathrm{~h}$ postglucose load. According to the International Association of the Diabetes and Pregnancy Study Groups [14], GDM was diagnosed with fasting blood sugar (FBS) of at least $92 \mathrm{mg} / \mathrm{dl}, 1 \mathrm{~h}$ postprandial of at least $180 \mathrm{mg} /$ $\mathrm{dl}$, or the $2-\mathrm{h}$ postprandial of at least $153 \mathrm{mg} / \mathrm{dl}$.

\section{Statistical analysis}

The collected data were coded, tabulated, and statistically analyzed using the statistical package for the social sciences
(SPSS) software, version 23 (SPSS Inc., Chicago, Illinois, USA). Descriptive statistics were done for parametric quantitative data by mean, SD, and the range, while they were performed for categorical data based on the number and percentage. Analyses were done for parametric quantitative data between two groups using independent sample $t$-test, and for nonparametric quantitative data using Mann-Whitney $U$-test. Analyses were done for qualitative data using $\chi^{2}$-test correlation between two quantitative variables was done by using Pearson's correlation coefficient and for qualitative ordinal variable by using nonparametric Spearman's $\rho$ correlation coefficient. Odds ratios were calculated for different risk factors using multiple logistic regression analyses $(P<0.05)$. The sensitivity, specificity, and the predictive values (positive and negative) of DIPSI in relation to IADPSG were calculated.

\section{Results}

Of the 780 consecutive pregnant women during the study period, 80 cases were excluded (68 because of chronic illness and 12 who did not come to do the $2 \mathrm{~h}$ $75 \mathrm{~g}$ OGTT), and the remaining 700 women were included. Of them, 505 (72.14\%) women were from rural areas and 195 (27.86\%) were from urban areas. Their mean age was $26.5 \pm 5.5$ years (range: $18-42$ ). The GDM was diagnosed in $62(8.86 \%)$ cases based on the DIPSI criteria. Upon evaluation of the patients with the IADPSG criteria, GDM was diagnosed in 52 (7.43\%) cases only (Fig. 1). The sensitivity, specificity, positive, and negative predictive value of DIPSI in comparison to the IADPSG criteria is about $100,98.5,83$, and $100 \%$, respectively.

Table 1 summarizes the demographic and baseline characteristics of the studied pregnant women. The

\section{Figure 1}

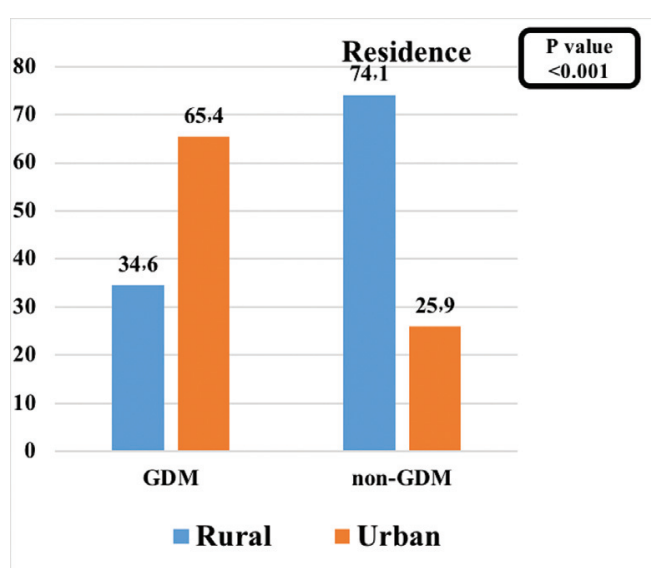

$\mathrm{BMI}$ in women with gestational diabetes versus control. 
mean age of the participants was $26.5 \pm 5.5$ years (range: 18-42 years), with 380 (54.28\%) of them under 25 years. The mean marital age was $20.4 \pm 2.2$ years (range: $17-34$ years). The mean body weight was $74.8 \pm 8.3 \mathrm{~kg}$ (range: $52-130 \mathrm{~kg}$ ). The mean BMI was $26.7 \pm 2.4$ (range: $21.8-47.2)$, with 609 (87\%) patients having a BMI of at least $25 \%$, and 91 (13\%) having a BMI of less than 25\%. Most of the participants (91.42\%) were housewives, while only $8.57 \%$ were working. On the basis of the educational state, 575 (82.14) patients have secondary education and above versus 125 (17.86\%) patients have less than a secondary education. The mean systolic blood pressure was $116.8 \pm 7.4$ (range: $100-140)$ and the mean diastolic blood pressure was 74.1 \pm 5.4 (range: 60-90).

Table 1 Baseline characteristics of the study population

\begin{tabular}{|c|c|}
\hline \multicolumn{2}{|l|}{ Age (years) } \\
\hline Range & $18-42$ \\
\hline Mean \pm SD & $26.5 \pm 5.5$ \\
\hline$<25$ (years) & $380(54.28)$ \\
\hline$>25$ (years) & $320(45.72)$ \\
\hline \multicolumn{2}{|l|}{ Marital age (years) } \\
\hline Range & $17-34$ \\
\hline Mean \pm SD & $20.4 \pm 2.2$ \\
\hline \multicolumn{2}{|l|}{ Body weight (kg) } \\
\hline Range & $52-130$ \\
\hline Mean \pm SD & $74.8 \pm 8.3$ \\
\hline \multicolumn{2}{|l|}{ Height (cm) } \\
\hline Range & $153-185$ \\
\hline Mean \pm SD & $167.3 \pm 4.8$ \\
\hline \multicolumn{2}{|l|}{ BMI $\left(\mathrm{kg} / \mathrm{m}^{2}\right)$} \\
\hline Range & $21.8-47.2$ \\
\hline Mean \pm SD & $26.7 \pm 2.4$ \\
\hline \multicolumn{2}{|l|}{ BMI $\left(\mathrm{kg} / \mathrm{m}^{2}\right)$} \\
\hline$<25$ & $91(13)$ \\
\hline$\geq 25$ & $609(87)$ \\
\hline \multicolumn{2}{|l|}{ Residence } \\
\hline Rural & $505(72.14)$ \\
\hline Urban & $195(27.86)$ \\
\hline \multicolumn{2}{|l|}{ Occupation } \\
\hline Housewife & $640(91.42)$ \\
\hline Worker & $60(8.58)$ \\
\hline \multicolumn{2}{|l|}{ Educational level } \\
\hline$<$ Secondary & $125(17.86)$ \\
\hline Illiterate & $32(4.6)$ \\
\hline Primary & $14(2)$ \\
\hline Preparatory & $79(11.3)$ \\
\hline Secondary or above & $575(82.14)$ \\
\hline Secondary & $454(64.9)$ \\
\hline High education & $121(17.3)$ \\
\hline \multicolumn{2}{|l|}{$\mathrm{SBP}(\mathrm{mmHg})$} \\
\hline Range & $100-140$ \\
\hline Mean \pm SD & $116.8 \pm 7.4$ \\
\hline \multicolumn{2}{|l|}{$\mathrm{DBP}(\mathrm{mmHg})$} \\
\hline Range & $60-90$ \\
\hline Mean \pm SD & $74.1 \pm 5.4$ \\
\hline
\end{tabular}

DBP, diastolic blood pressure; SBP, systolic blood pressure.
Table 2 presents the past obstetric history of the studied pregnant women. There was a past history of macrosomia in four $(0.57 \%)$ cases, twins in 10 (1.43\%) cases, abortions and stillbirths in $112(16 \%)$ cases, preterm labor in $36(5.14 \%)$ cases, gestational hypertension in $32(4.57 \%)$ cases, previous GDM in 11 (1.57\%) cases, polycystic ovary syndrome in two (0.29\%) cases, neonatal death in $17(2.43 \%)$ cases, and no history of preeclampsia. There was a family history of DM in 76 (10.9\%) cases.

Table 3 compares the demographic data between the GDM and non-GDM groups. The GDM group had significantly higher mean age, marital age, body weight, and BMI than the non-GDM group $(30.1 \pm 5.6$ vs. $26.2 \pm 5.3) \quad(22.2 \pm 3.0$ vs. $20.3 \pm 2.1)$ $(87.7 \pm 15.9$ vs. $73.7 \pm 6.1)$, and $(31.4 \pm 5.3$ vs. 26.3 \pm 1.5 ), respectively, with a $P$ value less than 0.001 for all. Most of the GDM patients were from urban areas (urban/rural: 65.4/34.6\%), but on the contrary most of the non-GDM patients were from rural areas [urban/rural: 25.9/74.1 $(P<0.001)$ ]. More than three-fourths of the patients in the GDM group were housewives $(76 / 23 \%)(P<0.001)$. Also, the GDM rate was found to be increased with a decrease in educational qualification, being highest in women below the secondary school level of education $(P<0.00)$.

Table 4 shows that GDM women had a statistically significant higher past history of macrosomia, abortions, stillbirth, gestational hypertension, polycystic ovary syndrome, family history of diabetes $(P<0.001$ for all), and $(P<0.01)$ for neonatal death.

Table 5 presents the multiple logistic regression analysis for prediction of GDM, BMI $[P<0.001$,

Table 2 Past obstetric history of the participants

\begin{tabular}{lcc}
\hline History & \multicolumn{2}{c}{ Descriptive statistics $(n=700)$} \\
\cline { 2 - 3 } & No $(\%)]$ & Yes \\
\hline Macrosomic baby & $696(99.43)$ & $4(0.57)$ \\
Twins & $690(98.57)$ & $10(1.43)$ \\
Abortions or stillbirths & $588(84)$ & $112(16)$ \\
Preterm labor & $664(94.86)$ & $36(5.14)$ \\
Malformation & $700(100)$ & $0(0)$ \\
Gestational HTN & $668(95.43)$ & $32(4.57)$ \\
Previous GDM & $689(98.43)$ & $11(1.57)$ \\
PCOS & $698(99.71)$ & $2(0.29)$ \\
Family history of DM & $624(89.1)$ & $76(10.9)$ \\
Neonatal death & $683(97.57)$ & $17(2.43)$ \\
Preeclampsia & $700(100)$ & $0(0)$ \\
\hline
\end{tabular}

DM, diabetes mellitus; GD, gestational diabetes mellitus; HTN, hypertension; PCOS, polycystic ovary syndrome. 
Table 3 Comparison of women with gestational diabetes versus control

\begin{tabular}{|c|c|c|c|}
\hline \multirow[t]{2}{*}{ Variables } & \multicolumn{2}{|c|}{ Participants } & \multirow[t]{2}{*}{$P$ value } \\
\hline & Control $(n=648)$ & GDM $(n=52)$ & \\
\hline \multicolumn{4}{|l|}{ Age } \\
\hline Range & $18-42$ & $20-42$ & 0.001 \\
\hline Mean $\pm S D$ & $26.2 \pm 5.3$ & $30.1 \pm 5.6$ & \\
\hline \multicolumn{4}{|l|}{ Marital age } \\
\hline Range & $17-34$ & $18-28$ & 0.001 \\
\hline Mean \pm SD & $20.3 \pm 2.1$ & $22.2 \pm 3$ & \\
\hline \multicolumn{4}{|l|}{ Parity } \\
\hline$<2$ & 246 (38) & $20(38.5)$ & 0.001 \\
\hline$\geq 2$ & 402 (62) & 32 (61.5) & \\
\hline \multicolumn{4}{|l|}{ Gravidity } \\
\hline$<2$ & $183(28.2)$ & $6(11.5)$ & 0.009 \\
\hline$\geq 2$ & 465 (71.8) & $46(88.5)$ & \\
\hline \multicolumn{4}{|l|}{ Body weight $(\mathrm{kg})$} \\
\hline Range & $52-124.6$ & $69-130$ & 0.001 \\
\hline Mean $\pm S D$ & $73.7 \pm 6.1$ & $88.7 \pm 15.9$ & \\
\hline \multicolumn{4}{|l|}{ Height (cm) } \\
\hline Range & $153-185$ & $159-177$ & 0.380 \\
\hline Mean \pm SD & $167.2 \pm 4.8$ & $167.8 \pm 4.6$ & \\
\hline \multicolumn{4}{|l|}{ BMI $\left(\mathrm{kg} / \mathrm{m}^{2}\right)$} \\
\hline Range & $21.8-39.8$ & $26.2-47.2$ & $<0.001^{*}$ \\
\hline Mean \pm SD & $26.3 \pm 1.5$ & $31.4 \pm 5.3$ & \\
\hline \multicolumn{4}{|l|}{ BMI $\left(\mathrm{kg} / \mathrm{m}^{2}\right)$} \\
\hline$<25$ & 84 (12.9) & $0(0)$ & $<0.001^{*}$ \\
\hline 25-29.9 & $557(86)$ & $30(57.7)$ & \\
\hline$\geq 30$ & $7(1.1)$ & $22(42.3)$ & \\
\hline \multicolumn{4}{|l|}{ Residence } \\
\hline Rural & $480(74.1)$ & $18(34.6)$ & $<0.001^{*}$ \\
\hline Urban & 168 (25.9) & $34(65.4)$ & \\
\hline \multicolumn{4}{|l|}{ Occupation } \\
\hline Housewife & $600(92.6)$ & $40(76.9)$ & $<0.001^{*}$ \\
\hline Worker & $48(7.4)$ & $12(23.1)$ & \\
\hline \multicolumn{4}{|l|}{ Educational level } \\
\hline$<$ Secondary & $109(16.8)$ & $16(30.8)$ & $<0.001^{*}$ \\
\hline Illiterate & $30(4.6)$ & $2(3.8)$ & \\
\hline Primary & $10(1.5)$ & $4(7.7)$ & \\
\hline Preparatory & $69(10.6)$ & $10(19.2)$ & \\
\hline$\geq$ Secondary & 539 (83.2) & $36(69.2)$ & \\
\hline Secondary & 436 (67.3) & $18(34.6)$ & \\
\hline High education & $103(15.9)$ & $18(34.6)$ & \\
\hline
\end{tabular}

confidence interval (CI): 1.529-2.475\%], urban residency $(P<0.001, \mathrm{CI}: 3.117-32.828 \%)$, gestational hypertension $(P<0.01, \mathrm{CI}: 1.542-44.084 \%)$ previous history of GDM $(P<0.01, \mathrm{CI}: 0.93-72.4 \%)$, family history of DM $(P<0.001$, CI: 2.290-27.594\%), and the educational level more than secondary school is a risk protective factor $(P<0.001, \mathrm{CI}$ : $0.041-0.464 \%)$.

Table 6 presents the comparison of mean age and BMI of the participants based on their residency. The mean BMI of women with urban residency was significantly higher as compared with those with rural residency $(P<0.001)$, but the age has
Table 4 Past obstetric history of gestational diabetes mellitus versus control

\begin{tabular}{|c|c|c|c|}
\hline History & $\begin{array}{c}\text { Non-GDM }(n=648) \\
{[n / N(\%)]}\end{array}$ & $\begin{array}{c}\text { GDM }(n=52) \\
{[n / N(\%)]}\end{array}$ & $P$ value \\
\hline $\begin{array}{l}\text { Macrosomic } \\
\text { baby }\end{array}$ & $0 / 648(0)$ & $4 / 52(7.69)$ & $<0.001^{*}$ \\
\hline Twins & $10 / 648(1.54)$ & $0 / 52(0)$ & 0.367 \\
\hline $\begin{array}{l}\text { Abortions or } \\
\text { stillbirth }\end{array}$ & $100 / 648(15.43)$ & 12/52 (23.07) & 0.148 \\
\hline Preterm labor & $34 / 648(5.24)$ & $2 / 52(3.84)$ & 0.660 \\
\hline Malformation & $0 / 648(0)$ & $0 / 52(0)$ & - \\
\hline $\begin{array}{l}\text { Gestational } \\
\text { hypertension }\end{array}$ & $18 / 648(2.77)$ & 14/52 (26.92) & $<0.001^{*}$ \\
\hline PCOS & $0 / 648(0)$ & $2 / 52(3.84)$ & $<0.001^{*}$ \\
\hline Family diabetes & $56 / 648(8.64)$ & $20 / 52(38.46)$ & $<0.001^{*}$ \\
\hline Neonatal death & $13 / 648(2.0)$ & $4 / 52(7.69)$ & $0.010^{*}$ \\
\hline Hirsutism & $0 / 648(0)$ & $0 / 52(0)$ & - \\
\hline Preeclampsia & $0 / 648(0)$ & $0 / 52(0)$ & - \\
\hline
\end{tabular}

GDM, gestational diabetes mellitus.

Table 5 Multiple logistic regression analysis for prediction of gestational diabetes mellitus

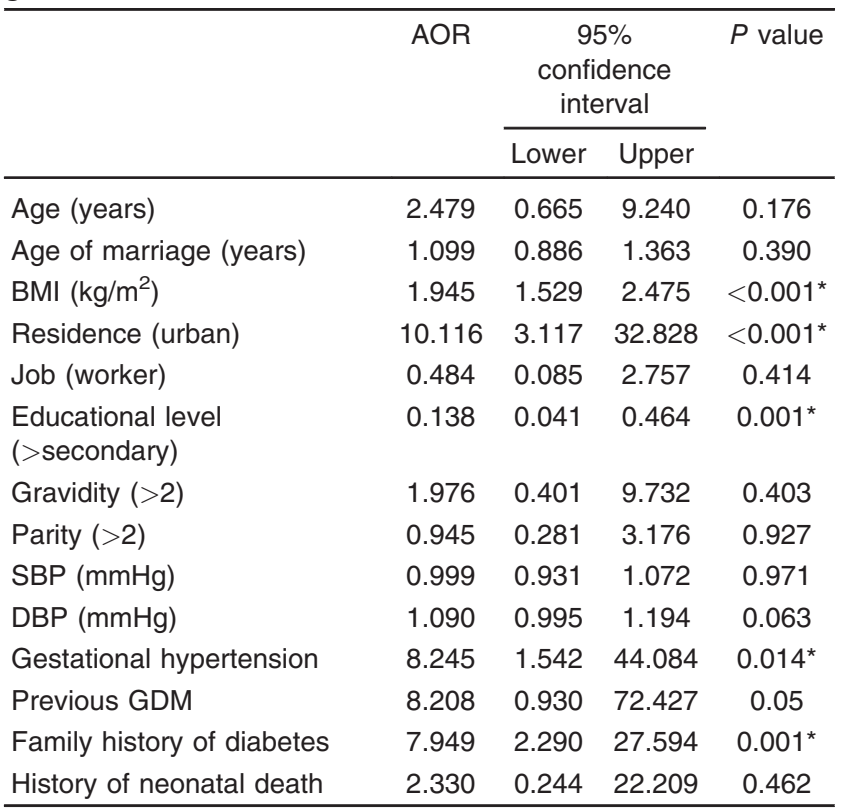

DBP, diastolic blood pressure; GDM, gestational diabetes mellitus; SBP, systolic blood pressure.

nonsignificant difference. This finding explains the higher percentage of urban residency in the GDM group (Figs 2-4).

\section{Discussion}

The prevalence of DM as a major noncommunicable disease in Egypt is rapidly growing probably due to the rapid sociodemographic changes $[15,16]$. Egypt was identified to be the ninth leading country worldwide in terms of the number of patients with DM with a prevalence rate of $15.9 \%$ [15]. Accordingly, it is not surprising to expect an increase in GDM prevalence despite the paucity of literature in this regard [17]. Therefore, this study 
was conducted to evaluate the prevalence of GDM in E1-Minya city, in Upper Egypt.

Due to the near similarity of the sociocultural status between Egypt and India, we find it wise to use the DIPSI as a simple, feasible, and single-step screening procedure. Its principle is based on that normal women could maintain an euglycemic state despite the glucose

Table 6 Comparison of mean age and BMI of participants based on residency

\begin{tabular}{lccc}
\hline Variables & \multicolumn{2}{c}{ Residence } & $P$ value \\
\cline { 2 - 3 } & Rural $(n=498)$ & Urban $(n=202)$ & \\
\hline Age & & & \\
$\quad$ Range & $18-42$ & $18-41$ & 0.373 \\
Mean \pm SD & $26.6 \pm 5.6$ & $26.2 \pm 4.9$ & \\
BMI $\left(\mathrm{kg} / \mathrm{m}^{2}\right)$ & & & \\
Range & $21.9-44.8$ & $21.8-47.2$ & $0.008^{*}$ \\
Mean \pm SD & $26.6 \pm 2.1$ & $27.1 \pm 3.1$ & \\
\hline
\end{tabular}

challenge; however, those women with impaired insulin secretion will respond with hyperglycemia [18]. Being a single-step test and evading the need for a second visit for diagnosis, offers a socioeconomic advantage for the Egyptian patients with low socioeconomic status. To evaluate the accuracy of DIPSI in comparison to the most credible method of screening for DM in the world, we did 2-h OGTT according to the IADPSG criteria.

This study revealed a GDM prevalence of $8.86 \%$ based on the DIPSI criteria versus $7.4 \%$ according to the IADPSG criteria. In comparison to the IADPSG criteria, the DIPSI test has shown a sensitivity and specificity of 100 and $98.5 \%$, respectively. Its positive and negative predictive values in comparison to IADDSG were about 83 and 100\%, respectively. These results were comparable to those of many authors: Khalil et al. [17] in Lower Egypt, Swami

Figure 2

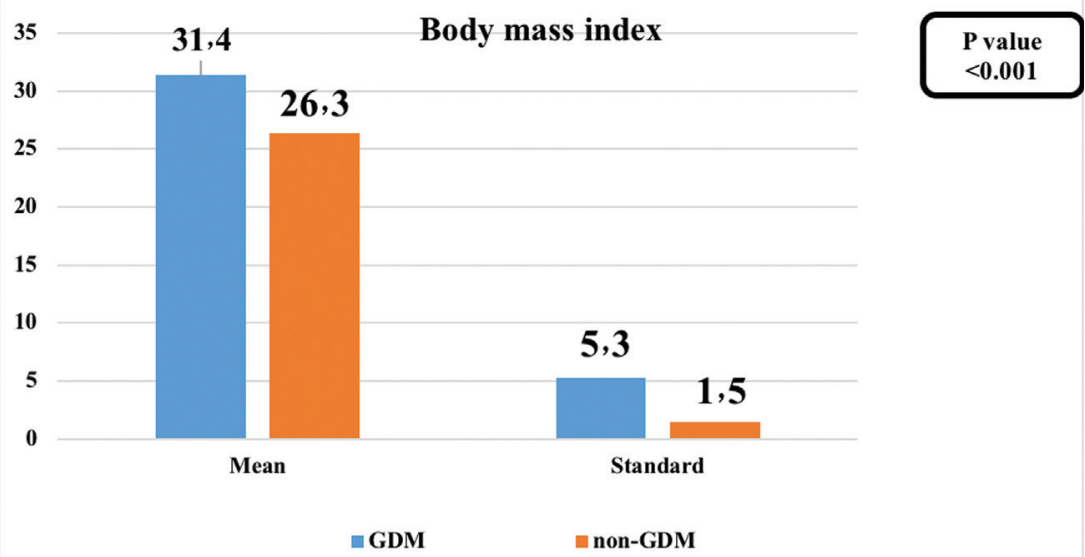

The state of residency in women with gestational diabetes versus control.

Figure 3

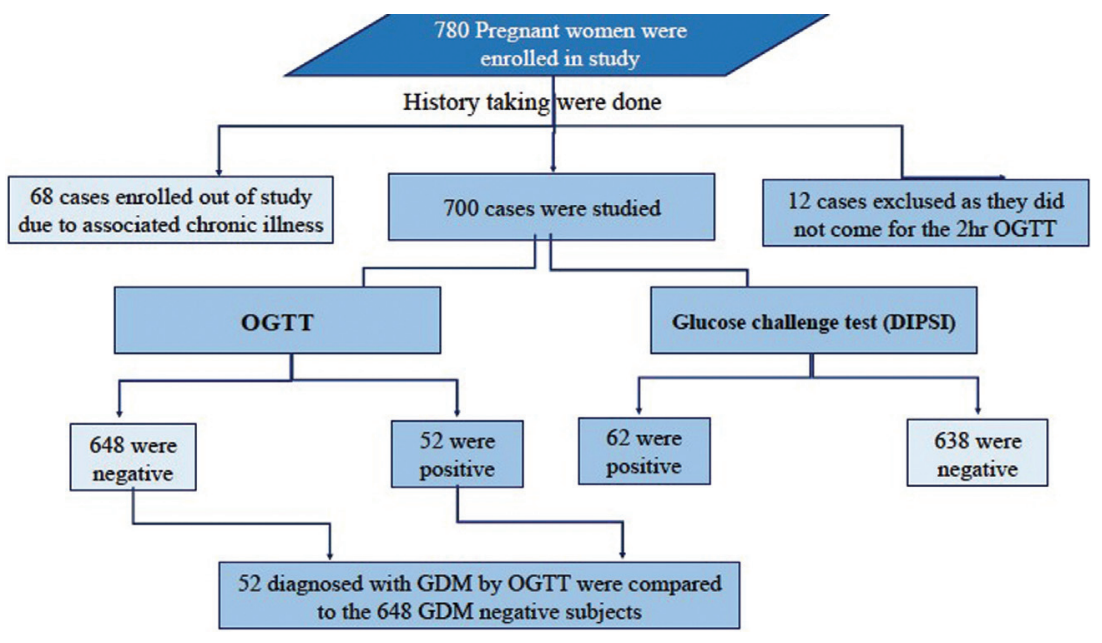

The level of education in women with gestational diabetes versus control. 


\section{Educational Level}

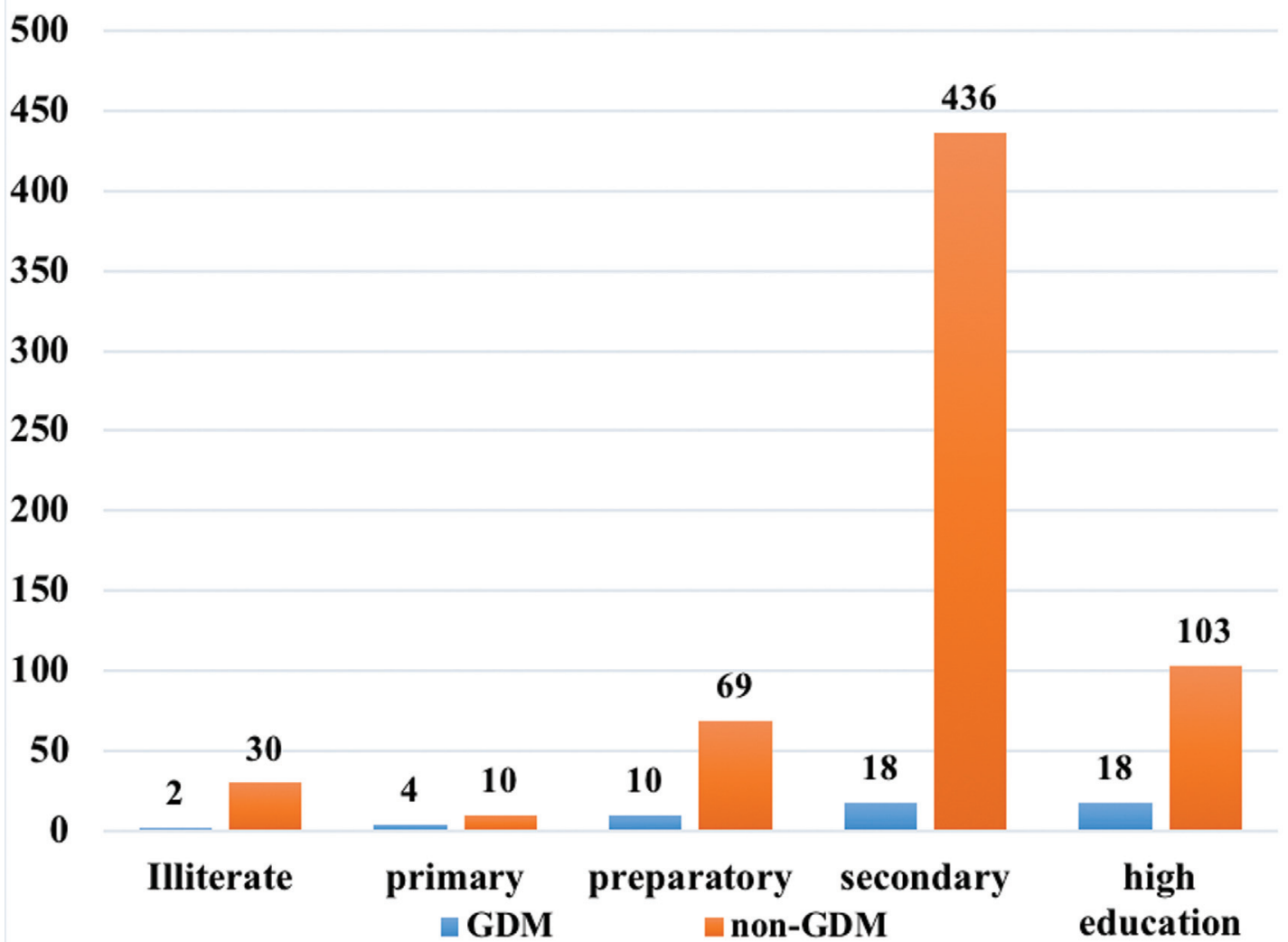

Flowchart showing recruitment of the study women and prevalence of GDM by DIPSI criteria, and ADA (IADPSG). DIPSI, Diabetes in Pregnancy Study Group India; GDM, gestational diabetes mellitus; IADPSG, International Association of the Diabetes and Pregnancy Study Groups; OGTT, oral glucose tolerance test.

et al. [19] from Nigeria, Anzaku and Musa [20] from India, and Seyoum et al. [21] from Morocco reported prevalence rates of $8,8.3,7.7$, and $7.7 \%$, respectively. On the contrary, Macaulay et al. [22] from Tanzania, Jafari-Shobeiri et al. [23] from Iran, and Agarwal [24] from Ethiopia reported GDM prevalence rates of 0 , 3.41 , and 3.7\%, respectively. These stark differences may be attributed to the difference in the diagnostic criteria used or the population studied to the extent that the results reported from five African countries such as Ethiopia, Morocco, Mozambique, Nigeria, and South Africa revealed prevalence figures ranging from 1.6 to $13.9 \%$.

Controversy still exists about the sensitivity and effectiveness of DIPSI versus the commonly used tests for GDM screening as the WHO and IADPSG. In agreement with Vijayalakshmi et al. [25], our results revealed a high sensitivity index for DIPSI test with more cases diagnosed for GDM than the IADPSG criteria. This may be explained by the diurnal variation in glucose tolerance, insulin sensitivity, and $\beta$-cell responsivity later in the day, taking into consideration that the DIPSI test can be done at any time in the day, while the IADPSG is usually done in the morning [26-29]. On the contrary, other studies $[30,31]$ have shown that the DIPSI test showed a lower sensitivity index with fewer cases being diagnosed for GDM compared with both WHO and IADPSG criteria. Despite the controversy about DIPSI as a screening tool of GDM, we agree with Seshiah et al. [32] in favor of DIPSI being a simple, single-step screening and diagnostic procedure, economical and easy to perform. It can be considered as a useful tool for comprehensive screening for GDM in the first visit, as well as in the 24-28 gestation weeks for antenatal care, while avoiding multiple complex tests in screening.

In concordance with other studies [33-35], the current study has shown that increasing maternal age was associated with increased GDM prevalence. In our cases, GDM was more frequent among those more than 30 years, while the normal control had a mean age of 24 years. Kanadys et al. [35] reported that maternal 
age of more than 35 years increases the risk of GDM by more than three times.

Although most of the participants in this study were residing in the countryside (75\%), the prevalence of the GDM was higher in those living in urban areas (65 vs. $34 \%)$. This can be explained in agreement with Macaulay et al. [22] that the transition from rural to urban lifestyle with changes in eating habits, western diet with increased consumption of fats, sugars and refined carbohydrates, increased body mass and decreased physical activity. This was evident in the current study. The mean BMI of women living in urban areas was much higher than those in rural areas $(27.1 \pm 3.1$ vs. $26.6 \pm 2.1, P=0.008)$.

In agreement with Yang et al. [36], this study has shown that the GDM group had a higher rate of parity of more than two children. On the contrary, Duman [37] reported no role for parity on the risk of GDM and Seghieri et al. [38] reported that parity is not directly related to insulin sensitivity degradation or GDM onset, unless it is associated with the effect of progressive aging and weight gain both before and during pregnancy. This difference is most likely to be explained by the differences in sample population or age.

We agree with Soheilykhah et al. [39], Rajput et al. [40], and Erem et al. [8] that the family history of DM had a significant relationship with the evolution of GDM in the studied group.

Obesity has been reported to be an important risk factor for the development of GDM [19,33,41]. In agreement with Rajput et al. [40], our study revealed that the prevalence of GDM was significantly higher in women with higher BMI and higher body weight. Bianco et al. [42] reported a three-fold higher risk of developing GDM in obese women than in nonobese women [43], 3.76 times in women with a BMI of at least $30 \mathrm{~kg} / \mathrm{m}^{2}$ [44], and up to 60 times more likely to develop GDM in women with at least $30 \mathrm{~kg} / \mathrm{m}^{2}$ than those with a BMI of less than $18.5 \mathrm{~kg} / \mathrm{m}^{2}$. Even prepregnancy $\mathrm{BMI}$ and obesity were reported in several studies to be associated with higher prevalence of GDM and represent independent risk factors for GDM [8].

The most important factor affecting insulin sensitivity is unsaturated fatty acids. Pancreatic $\beta$-cells increase insulin release in case of increased insulin resistance to maintain euglycemia. These cells may be a victim of dysfunction with constant exposure to high levels of unsaturated fatty acids resulting in type 2 diabetes. Excessive adipose tissue leads to excessive release of unsaturated fatty acids. Similarly, GDM may develop through the same mechanism [45].

The educational level is considered as an indicator of the low socioeconomic position (SEP) [46]. Low SEP has been identified as a major risk factor for the development of type $2 \mathrm{DM}[47,48]$ as well as GDM [49]. This risk may be explained by the relatively high rates of overweight and obesity in this group of people. In agreement with Bo et al. [50] and Bouthoorn et al. [46], we found that women with less than secondary education had an increased risk of GDM. Logistic regression analysis showed that education higher than the secondary school level is risk protective against GDM [odds ratio (OR): $0.138 ; 95 \%$ CI: $0.041-0.464]$. On the contrary, other studies did not find any association between GDM with education in Chinese pregnant women [36], or with SEP [51,52].

In agreement with Erem et al. [8], Khalil et al. [17], and Leng et al. [53], our study revealed that gestational hypertension was significantly higher in the GDM group. This was confirmed with regression analysis. On the contrary, Zokaie et al. [34] reported a nonsignificant difference between GDM cases and the control group regarding blood pressure measurement.

In concordance with Pridjian and Benjamin [4], Erem et al. [8], and Khalil et al. [17], our findings have shown that macrosomia was significantly associated with previous history of GDM.

\section{Conclusion}

The DIPSI criteria may be a suitable tool for GDM screening in our area. The overall prevalence of GDM by DIPSI was $8.86 \%$ with a positive predictive value of $84 \%$ in relation to IADPSG. The risk factors for GDM development were increased BMI, urban residency, education lower than the secondary level, family history of DM, and gestational hypertension.

\section{Acknowledgements}

The authors thank Professor Fatma El Zahra Albukhary for her continuous support and useful guidance.

\section{Financial support and sponsorship}

Nil. 


\section{Conflicts of interest}

There are no conflicts of interest.

\section{References}

1 Ben-Haroush A, Yogev Y, Hod M. Epidemiology of gestational diabetes mellitus and its association with type 2 diabetes. Diabet Med 2004; 21:103-113.

2 Reece EA, Leguizamón G, Wiznitzer A. Gestational diabetes: the need for a common ground. Lancet 2009; 373:1789-1797.

3 Petry CJ. Gestational diabetes: risk factors and recent advances in its genetics and treatment. Br J Nutr 2010; 104:775-787.

4 Pridjian G, Benjamin TD. Update on gestational diabetes. Obstet Gynecol Clin North Am 2010; 37:255-267.

5 Jang HC. Gestational diabetes in Korea: incidence and risk factors of diabetes in women with previous gestational diabetes. Diabetes Metab J 2011; 35:1-7.

6 Yang H, Wei Y, Gao X, Xu X, Fan L, He J, et al. Risk factors for gestational diabetes mellitus in Chinese women: a prospective study of 16,286 pregnant women in China. Diabet Med 2009; 26:1099-1104.

7 Di Cianni G, Volpe L, Lencioni C, Miccoli R, Cuccuru I, Ghio A, et al. Prevalence and risk factors for gestational diabetes assessed by universal screening. Diabetes Res Clin Pract 2003; 62:131-137.

8 Erem C, Kuzu UB, Deger O, Can G. Prevalence of gestational diabetes mellitus and associated risk factors in Turkish women: the Trabzon GDM Study. Arch Med Sci 2015; 11:724-735.

9 Dode MAS de O, dos Santos IS. Non-classical risk factors for gestational diabetes mellitus: a systematic review of the literature. Cad Saude Publica 2009; 25(Suppl 3):S341-S359.

10 Wendland EM, Pinto ME, Duncan BB, Belizán JM, Schmidt MI. Cigarette smoking and risk of gestational diabetes: a systematic review of observational studies. BMC Pregnancy Childbirth 2008; 8:53.

11 Hossein-Nezhad A, Maghbooli Z, Vassigh AR, Larijani B. Prevalence of gestational diabetes mellitus and pregnancy outcomes in Iranian women. Taiwan J Obstet Gynecol 2007; 46:236-241.

12 Lemeshow S, Hosmer DW, Klar J, Lwanga SK, Organization WH. Adequacy of sample size in health studies. 1990. Available at: http:// www.who.int/iris/handle/10665/4160. [Accessed 23 February 2018].

13 National guidelines for diagnosis and management of gestational diabetes mellitus. New Delhi. Maternal Health Division, Ministry of Health \& Family Welfare. New Delhi: Government of India; 2015.

14 International Association of Diabetes and Pregnancy Study Groups Consensus Panel. International association of diabetes and pregnancy study groups recommendations on the diagnosis and classification of hyperglycemia in pregnancy. Diabetes Care 2010; 33:676-682.

15 Hegazi R, El-Gamal M, Abdel-Hady N, Hamdy O. Epidemiology of and risk factors for type 2 diabetes in Egypt. Ann Glob Health 2015; 81:814-820.

16 Mashahit M, Ezzat E, Hanafy E. Prevalence of non-communicable diseases in patients with type 2 diabetes mellitus in egypt; a retrospective survey. Asian J Med Health 2017; 7:1-9.

17 Khalil NA, Fathy WM, Mahmoud NS. Screening for gestational diabetes among pregnant women attending a rural family health center, Menoufia Governorate, Egypt. J Fam Med Health Care 2017; 3:6.

18 Catalano PM, Tyzbir ED, Wolfe RR, Calles J, Roman NM, Amini SB, Sims EA. Carbohydrate metabolism during pregnancy in control subjects and women with gestational diabetes. Am J Physiol 1993; 264:E60-E67.

19 Swami SR, Mehetre R, Shivane V, Bandgar TR, Menon PS, Shah NS. Prevalence of carbohydrate intolerance of varying degrees in pregnant females in western India (Maharashtra) - a hospital-based study. J Indian Med Assoc 2008; 106:712-714.

20 Anzaku AS, Musa J. Prevalence and associated risk factors for gestational diabetes in Jos, North-central, Nigeria. Arch Gynecol Obstet 2013; 287:859-863.

21 Seyoum B, Kiros K, Haileselase T, Leole A. Prevalence of gestational diabetes mellitus in rural pregnant mothers in northern Ethiopia. Diabetes Res Clin Pract 1999; 46:247-251.

22 Macaulay S, Dunger DB, Norris SA. Gestational diabetes mellitus in Africa: a systematic review. PLoS One 2014; 9:e 97871.

23 Jafari-shobeiri M, Ghojazadeh M, Azami-aghdash S, Naghavi-bdhzad M, Piri R, Pourali-akbar $\mathrm{Y}$, et al. Prevalence and risk factors of gestational diabetes in Iran: a systematic review and meta-analysis. Iran J Public Health 2015; 44:1036-1044.
24 Agarwal MM. Gestational diabetes mellitus: an update on the current international diagnostic criteria. World J Diabetes 2015; 6:782-791.

25 Vijayalakshmi UB, Adusumalli P, Venkata RG, Pernenkil S. Effectiveness of Diabetes in Pregnancy Study Group India (DIPSI) Diagnostic Criterion in Detecting Gestational Diabetes Mellitus - a Pilot Study in a Rural Population. Indian J Basic Appl Med Res 2013; 2:614-618.

26 Lee A, Ader M, Bray GA, Bergman RN. Diurnal variation in glucose tolerance. Cyclic suppression of insulin action and insulin secretion in normal-weight, but not obese, subjects. Diabetes 1992; 41:750-759.

27 Goldberg RJ, Ye C, Sermer M, Connelly PW, Hanley AJG, Zinman B, Retnakaran R. Circadian variation in the response to the glucose challenge test in pregnancy: implications for screening for gestational diabetes mellitus. Diabetes Care 2012; 35:1578-1584.

28 McElduff A, Hitchman R. Screening for gestational diabetes: the time of day is important. Med J Aust 2002; 176:136.

29 Wong VW, Garden F, Jalaludin B. Hyperglycaemia following glucose challenge test during pregnancy: when can a screening test become diagnostic? Diabetes Res Clin Pract 2009; 83:394-396.

30 Vij P, Jha S, Gupta SK, Aneja A, Mathur R, Waghdhare S, Panda M. Comparison of DIPSI and IADPSG criteria for diagnosis of GDM: a study in a north Indian tertiary care center. Int J Diabetes Dev Ctries 2015; 35:285-288.

31 Mohan V, Mahalakshmi MM, Bhavadharini B, Maheswari K, Kalaiyarasi G, Anjana RM, et al. Comparison of screening for gestational diabetes mellitus by oral glucose tolerance tests done in the non-fasting (random) and fasting states. Acta Diabetol 2014; 51:1007-1013.

32 Seshiah V, Balaji V, Balaji MS, Sekar A, Sanjeevi CB, Green A. One step procedure for screening and diagnosis of gestational diabetes mellitus. $J$ Obstet Gynecol India 2005; 55:525-529.

33 Seshiah V, Balaji V, Balaji MS, Paneerselvam A, Arthi T, Thamizharasi M, Datta M. Prevalence of gestational diabetes mellitus in South India (Tamil Nadu) - a community based study. J Assoc Physicians India 2008; 56:329-333.

34 Zokaie M, Majlesi F, Rahimi-Foroushani A, Esmail-Nasab N. Risk factors for gestational diabetes mellitus in Sanandaj, Iran.Chronic Dis J 2014; 2:1-9.

35 Kanadys WM. Occurrence of gestational diabetes mellitus: prognostic value of diabetes risk factors. Arch Perinat Med 2009; 15:106-111.

36 Yang X, Hsu-Hage B, Zhang H, Yu L, Dong L, Li J, et al. Gestational diabetes mellitus in women of single gravidity in Tianjin City, China. Diabetes Care 2002; 25:847-851.

37 Duman NK. Frequency of gestational diabetes mellitus and the associated risk factors. Pak J Med Sci 2015; 31:194-197.

38 Seghieri G, De Bellis A, Anichini R, Alviggi L, Franconi F, Breschi MC. Does parity increase insulin resistance during pregnancy? Diabet Med 2005; 22:1574-1580.

39 Soheilykhah S, Mogibian M, Rahimi-Saghand S, Rashidi M, Soheilykhah S, Piroz M. Incidence of gestational diabetes mellitus in pregnant women. Iran J Reprod Med 2010; 8:24-28.

40 Rajput R, Yadav Y, Nanda S, Rajput M. Prevalence of gestational diabetes mellitus \& associated risk factors at a tertiary care hospital in Haryana. Indian J Med Res 2013; 137:728-733.

41 Torloni MR, Betrán AP, Horta BL, Nakamura MU, Atallah AN, Moron AF, Valente O. Prepregnancy BMI and the risk of gestational diabetes: a systematic review of the literature with meta-analysis. Obes Rev 2009; 10:194-203.

42 Bianco AT, Smilen SW, Davis Y, Lopez S, Lapinski R, Lockwood CJ. Pregnancy outcome and weight gain recommendations for the morbidly obese woman. Obstet Gynecol 1998; 91:97-102.

43 Cypryk K, Szymczak W, Czupryniak L, Sobczak M, Lewinski A. Gestational diabetes mellitus - an analysis of risk factors. Endokrynol Pol 2008; 59:393-397.

44 Ali AD, Mehrass AA, Al-Adhroey AH, Al-Shammakh AA, Amran AA. Prevalence and risk factors of gestational diabetes mellitus in Yemen. Int J Womens Health 2016; 25:35-41.

45 Sivan E, Boden G. Free fatty acids, insulin resistance, and pregnancy. Curr Diab Rep 2003; 3:319-322.

46 Bouthoorn SH, Silva LM, Murray SE, Steegers EA, Jaddoe VW, Moll H. Low-educated women have an increased risk of gestational diabetes mellitus: the Generation R Study. Acta Diabetol 2015; 52:445-452.

47 Evans JM, Newton RW, Ruta DA, MacDonald TM, Morris AD. Socioeconomic status, obesity and prevalence of type 1 and type 2 diabetes mellitus. Diabet Med 2000; 17:478-480. 
48 Agardh EE, Ahlbom A, Andersson T, et al. Explanations of socioeconomic differences in excess risk of type 2 diabetes in Swedish men and women. Diabetes Care 2004; 27:716-721.

49 Anna V, van der Ploeg HP, Cheung NW, Huxley RR, Bauman AE. Sociodemographic correlates of the increasing trend in prevalence of gestational diabetes mellitus in a large population of women between1995 and 2005. Diabetes Care 2008; 31:2288-2293.

50 Bo S, Menato G, Bardelli C, et al. Low socioeconomic status as a risk factor for gestational diabetes. Diabetes Metab 2002; 28:139-140.
51 Shen JJ, Tymkow C, MacMullen N. Disparities in maternal outcomes among four ethnic populations. Ethn Dis 2005; 15:492-497.

52 Janghorbani M, Stenhouse EA, Jones RB, Millward BA. Is neighbourhood deprivation a risk factor for gestational diabetes mellitus? Diabet Med 2006 23:313-317.

53 Leng J, Shao P, Zhang C, Tian H, Zhang F, Zhang S, et al. Prevalence of gestational diabetes mellitus and its risk factors in chinese pregnant women: a prospective population-based study in Tianjin, China. PLoS One 2015; 10:e0121029. 